\title{
Hydrogeochemical characteristic of thermal waters in Bańska Niżna
}

\author{
Klaudia Korzec \\ AGH University of Science and Technology, Faculty of Geology, Geophysics and Environmental Protection; \\ al. A. Mickiewicza 30,30-059 Krakow, Poland; e-mail: kkorzec@agh.edu.pl
}

(C) 2016 Authors. This is an open access publication, which can be used, distributed and reproduced in any medium according to the Creative Commons CC-BY 4.0 License requiring that the original work has been properly cited.

Thermal waters belong to the greatest treasures of Podhale. They are used not only in heat engineering but also in recreation, medicine and rehabilitation (Kępińska 2004, 2009, Tomaszewska 2009). It is also known that thermal waters are treated and used for drinking or commercial purposes (Bujakowski \& Tomaszewska 2007, Tomaszewska 2009, 2011, Tomaszewska \& Bodzek 2013). Thermal waters in Bańska Niżna are exploited by PEC Geotermia Podhalańska S.A. Company. Commercial use of these waters began in 1993, when the system based on geothermal doublet, supplied heat to several houses (Ślimak \& Wartak 2009). Currently, the exploitation is made by using three wells: Bańska IG-1 well, Bańska PGP-1 well and Bańska PGP-3 well.

Hydrogeochemical characteristic of thermal waters in Bańska Niżna was based on researches concerning the state of those waters, which was being carried out every two weeks between December 2013 and August 2015. Field research was based on measurements of non-stable parameters - $\mathrm{pH}$, electrical conductivity $\gamma_{25}$ and the temperature on the flow. The results of field measurements were supplemented with archival data: water temperature at the well head, pressure and well discharge.

The samples for laboratory tests were taken by the author of this work in accordance with the standard ISO 5667-11:2004. The chemical composition analysis of thermal waters was carried out by accredited Hydrogeochemical Laboratory of the Department of Hydrogeology and Engineering Geology AGH in Kraków (certificate of Polish Centre of Accreditation No. AB 1050). This analysis included measurements of concentration of 45 indicators. On the basis of the results of the research, the hydrogeochemical type of thermal waters in Bańska Niżna was defined as sulfate-chloride-sodium-calcium type (according to the classification by Shchukarev-Priklonskiy (Prikłoński \& Łaptiew 1955)).

The medium values of the basic parameters of analyzed wells, estimated on the basis of data from 2013-2015, are as follows:

- Bańska IG-1 well: pH 6.63, $\gamma_{25} 3.48 \mathrm{mS} / \mathrm{cm}$, temperature at the well head $78.5^{\circ} \mathrm{C}$, pressure $11.8 \mathrm{ba}$, well discharge $58.1 \mathrm{~m}^{3} / \mathrm{h}$, mineralization $2522.8 \mathrm{mg} / \mathrm{dm}^{3}$;

- Bańska PGP-1: pH 6.69, $\gamma_{25} 3,39 \mathrm{mS} / \mathrm{cm}$, temperature at the well head $85.9^{\circ} \mathrm{C}$, pressure $14.4 \mathrm{ba}$, well discharge $317.3 \mathrm{~m}^{3} / \mathrm{h}$, mineralization $2533.6 \mathrm{mg} / \mathrm{dm}^{3}$;

- Bańska PGP-3: pH 6.72, $\gamma_{25} 3.43 \mathrm{mS} / \mathrm{cm}$, temperature at the well head $85.0^{\circ} \mathrm{C}$, pressure $14.0 \mathrm{ba}$, well discharge $221.3 \mathrm{~m}^{3} / \mathrm{h}$, mineralization $2514.3 \mathrm{mg} / \mathrm{dm}^{3}$.

The database from the years 2013-2015 was supplemented by archival results of chemical composition analyzes. On that basis, the assessment of the thermal waters chemical composition stability in Bańska Niżna was prepared, according to the scheme presented in work (Kmiecik \& Korzec 2015). It is especially important because physical parameters and chemical composition of geothermal waters can be change during the long-term exploitation. According to Polish law, 
confirm stability of the physico-chemical parameters is necessary because using these waters in medicine (Dz.U. 2011, nr 163, poz. 981 art. 5).

Moreover, the hydrogeochemical model of formation of those waters was defined.

The author of the paper would like to thank the PEC Geotermia Podhalańska S.A. Company for the opportunity to make the research and for available databases.

The study was partially supported by AGH UST 11.11.140.026 and AGH UST 15.11.140.483.

\section{REFERENCES}

Bujakowski W. \& Tomaszewska B., 2007. Program prac zmierzających do oceny możliwości uzdatniania wód termalnych. Technika Poszukiwań Geologicznych. Geotermia. Zrównoważony Rozwój, 1, 3-8.

Kępińska B., 2004. Podhalański system geotermalny i projekt ciepłowniczy - przegląd problematyki. [in:] Kępińska B. \& Popovski K. (red.), Międzynarodowe Dni Geotermalne Polska 2004: materiały międzynarodowej konferencji, Wydawnictwo Instytutu Gospodarki Surowcami Mineralnymi i Energią PAN, Kraków - Skopje, 243-257.

Kępińska B., 2009. Znaczenie badań podhalańskiego systemu geotermalnego dla eksploatacji wód geotermalnych.
Technika Poszukiwań Geologicznych. Geotermia. Zrównoważony Rozwój, 2, 29-48.

Kmiecik E. \& Korzec K., 2015. Ocena stabilności składu chemicznego wód termalnych ujmowanych otworem Bańska PGP-1 w Bańskiej Niżnej, Podhale. Przegląd Geologiczny, 63, 10/1, 830-833.

PN-ISO 5667-11:2004 Jakość wody - Pobieranie próbek Część 11: Wytyczne dotyczace pobierania próbek wód podziemnych. PKN, Warszawa.

Prikłoński W.A. \& Łaptiew F.F., 1955. Właściwości fizyczne i skład chemiczny wód podziemnych. Wydawnictwa Geologiczne. Warszawa.

Ślimak C. \& Wartak W., 2009. PEC Geotermia Podhalańska S.A. Doświadczenia, stan obecny, perspektywy rozwoju. Technika Poszukiwań Geologicznych. Geotermia. Zrównoważony Rozwój, 2, 123-132.

Tomaszewska B. \& Bodzek M., 2013. Desalination of geothermal water using hybrid UF-RO process. Part I: Boron removal in pilot-scale tests. Desalination, 319, 99-106.

Tomaszewska B., 2009. Uzdatnianie wód termalnych ujętych otworem Bańska IG-1 do celów pitnych jako jeden z kierunków ich kompleksowego wykorzystania. Technika Poszukiwań Geologicznych. Geotermia. Zrównoważony Rozwój, 2, 21-28.

Tomaszewska B., 2011. The use of ultrafiltration and reverse osmosis in the desalination of low mineralized geothermal waters. Archives Environmental Protection, 37, 3, 63-77.

Ustawa $z$ dnia 9 czerwca 2011 r. - Prawo geologiczne i górnicze. Dz.U. 2011, nr 163, poz. 981. 